\title{
Aspek biologi reproduksi ikan pari blentik Neotrygon kuhlii di perairan Selat Sunda
}

\section{Biology reproduction aspect of bluespotted stingray Neotrygon kuhliii in Sunda Strait}

\author{
Salma Abubakar, Mennofatria Boer*, Sulistiono \\ Departemen Manajemen Sumberdaya Perairan, Fakultas Perikanan dan Ilmu Kelautan, Institut Pertanian Bogor \\ Kampus IPB Dramaga Bogor, Jawa Barat 16680 \\ *surel: mboer@centrin.net.id
}

\begin{abstract}
Bluespotted stingray fish Neotrygon kuhlii is the important fish economically captured from Sunda Strait. Intensive fishing could decrease bluespotted stingray stock. This study was aimed to know the length-weight, and reproduction characteristic. The reproduction characteristic covered the size of first gonad maturity, the level and also index of gonad maturity of bluespotted stingray fish in Labuan Fishing Dock, Banten. The result showed the equilibrium of length-weight of female fish was about W=0.0007L2,1496. Meanwhile, the male fish was about W=0.0000L2.251. Male fish was better than female fish according their relatively condition factor. Decreasing of the factor condition was caused by feeding habit to grow the reproduction cells. The size of first gonad maturity for the female and male respectively were about 550-799 dan 550-760 $\mathrm{mm}$. The highest level maturity even female or male was on IV achieved in June and Juli 2013. Increasing the index (IKG) was followed by the level of gonad maturity.
\end{abstract}

Kata kunci: bluespotted stingray, reproductive characteristic, condition factor, Sunda Strait

\begin{abstract}
ABSTRAK
Ikan pari blentik Neotrygon kuhlii merupakan salah satu sumberdaya ikan ekonomis penting dan sebagai hasil penangkapan di Selat Sunda. Penangkapan yang intensif dapat mengakibatkan penurunan stok ikan pari blentik. Penelitian ini bertujuan untuk mengetahui panjang bobot, dan karakteristik reproduksi. Karaktersitik reproduksi itu sendiri meliputi ukaran pertama kali matang gonad, tingkat kematangan gonad dan indeks kematangan gonad ikan pari blentik di perairan Selat Sunda yang didaratkan di Pelabuhan Perikanan Pantai (PPP) Labuan, Banten. Berdasarkan hubungan panjang bobot ikan pari betina diperoleh persamaan hubungan panjang dan bobot untuk ikan pari blentik betina $\mathrm{W}=0,0007 \mathrm{~L} 2,1496$. Sementara itu pada ikan jantan, persamaan hubungan panjang bobot $\mathrm{W}=0,0000 \mathrm{~L} 2,251$. Ikan pari blentik jantan mempunyai faktor kondisi yang relatif lebih besar daripada ikan pari betina. Penurunan nilai faktor kondisi disebabkan bagian terbesar dari makanan yang dikonsumsi digunakan untuk perkembangan sel-sel reproduksinya. Kisaran ukuran pertama kali matang gonad ikan pari blentik betina 550-799, sedangkan untuk ikan pari jantan adalah dengan kisaran panjang total tubuh 550-760 mm. Tingkat kematangan gonad tertinggi ikan betina dan jantan (TKG IV) ditemukan pada bulan Juni dan Juli 2013. Indeks kematangan gonad (IKG) ikan pari semakin meningkat seiring dengan meningkatnya TKG.
\end{abstract}

Keywords: ikan pari blentik, karakteristik reproduksi, faktor kondisi, Selat Sunda

\section{PENDAHULUAN}

Ikan pari blentik Neotrygon kuhlii merupakan salah satu jenis ikan demersal yang dominan didaratkan di PPP Labuan. Pemanfaatan yang tinggi terhadap ikan pari blentik ini menuntut adanya pengelolaan yang salah satunya didasarkan pada aspek biologi seperti hubungan panjang-bobot, tingkat kematangan gonad dan faktor kondisi. Analisis hubungan panjang dan bobot dilakukan dengan tujuan untuk mengetahui konversi ukuran panjang ke bobot atau sebaliknya sehingga dapat dijadikan petunjuk kesehatan, kegemukan, produktivitas dan kondisi fisiologis termasuk perkembangan gonad (Hale et al., 2008). Pada perairan laut, ikan pari mempunyai peran 
ekologis yang sangat penting, terutama sebagai predator bentos. Namun beberapa aspek biologi (misalnya: reproduksi, makanan dan fisiologi) ikan pari belum dikaji secara menyeluruh (Pierce et al., 2009).

Ikan pari merupakan salah satu jenis ikan yang termasuk kelas Elasmobranchii. Ikan ini dikenal sebagai ikan batoid, yaitu kelompok ikan bertulang rawan yang mempunyai ekor seperti cambuk (White, 2003). Ikan pari memiliki celah insang yang terletak di sisi ventral kepala. Sirip dada ikan ini melebar menyerupai sayap, dengan sisi bagian depan bergabung dengan kepala. Bagian tubuh sangat pipih sehingga memungkinkan untuk hidup di dasar laut. Bentuk ekor seperti cambuk pada beberapa spesies dengan sebuah atau lebih duri tajam di bagian ventral dan dorsal (Puckridge et al., 2013). Ikan pari memiliki ciri yang unik dan berbeda dengan ikan lainnya yaitu struktur tubuh yang terdiri atas tulang rawan dan sifatnya sebagai predator (Chandramila \& Junardi, 2006). Last dan Stevens (2009) menyatakan bahwa ikan pari (famili Dasyatidae) mempunyai variasi habitat yang sangat luas dengan pola sebaran yang unik. Daerah sebaran ikan pari adalah perairan pantai dan kadang masuk ke daerah pasang surut.

Ikan pari blentik $N$. kuhlii merupakan salah satu sumberdaya ikan yang bernilai ekologi dan nilai ekonomis serta memiliki peranan penting dalam perikanan Indonesia. Salah satu daerah yang memiliki potensi perikanan pari yang sangat baik di Indonesia adalah perairan Selat Sunda, Propinsi Banten. Pentingnya sumberdaya ikan bagi kebutuhan manusia, baik untuk pemenuhan gizi maupun kegiatan perekonomian, mendorong manusia untuk mengeksploitasi sumberdaya ikan sebanyak-banyaknya, termasuk ikan pari. Pemanfaatan intensif terhadap sumberdaya ini menuntut adanya upaya pengelolaan yang baik.

Agar pemanfaatan sumberdaya ikan pari blentik di perairan Selat Sunda tetap lestari maka perlu dilakukan pengelolaan yang rasional salah satunya dengan mempertimbangkan aspek biologi. Penelitian ini bertujuan untuk menganalisa hubungan panjang-bobot, faktor kondisi ikan dan tingkat kematangn gonad ikan pari blentik di perairan Selat Sunda. Hasil dari penelitian ini diharapkan dapat dijadikan bahan masukan bagi studi populasi dan kebijakan pemanfaatan sumberdaya ikan pari blentik di Selat Sunda.

White dan Dharmadi (2007) menyatakan bahwa ikan pari jenis N. kuhlii (rays) hampir bisa dijumpai diseluruh perairan Indonesia. Last dan Stevens (2009) ikan pari merupakan ikan bertulang rawan dalam grup Cartilaginous. Ikan pari mempunyai bentuk tubuh gepeng melebar (depressed), sepasang sirip dada (pectoral fins) melebar dan menyatu dengan sisi kiri-kanan kepalanya, sehingga tampak atas atau bawahnya terlihat bundar atau oval. Ikan pari umumnya mempunyai ekor yang sangat berkembang (memanjang) menyerupai cemeti (Gambar 1).

\section{BAHAN DAN METODE}

\section{Waktu dan lokasi penelitian}

Penelitian ikan pari blentik di Selat Sunda dilakukan melalui pengumpulan data yang dilakukan di tempat pendaratan ikan utama yaitu PPP Labuan, Banten. Pengumpulan data dilakukan di PPP Labuan, tepatnya di TPI II, IIIdan TPI Panimbang sebagai tempat pendaratan untuk ikan-ikan demersaltermasuk ikan pari blentik. Pengumpulan data dilakukan pada JuliOktober 2013 dalam selang waktu 15-20 hari.

\section{Pengumpulan data}

Ikan pari blentik hasil tangkapan nelayan di Selat Sunda dikumpulkan dengan menggunakan metode penarikan contoh acak berlapis (PCAB). Data yang digunakan dalam penelitian ini meliputi :

a. Pengukuran panjang total dilakukan dengan pengaris dengan ketelitian $1 \mathrm{~mm}$

b. Penimbangan bobot ikan dilakukan dengan cara menimbang seluruh tubuh ikan menggunakan timbangan digital dengan ketelitian $0.1 \mathrm{~g}$

c. Penentuan tingkat kematangan gonad (kematangan seksual)

Kematangan seksual pada ikan pari blentik jantan dilakukan secara visual dengan melihat perkembangan dari mixopetrygia (klasper).

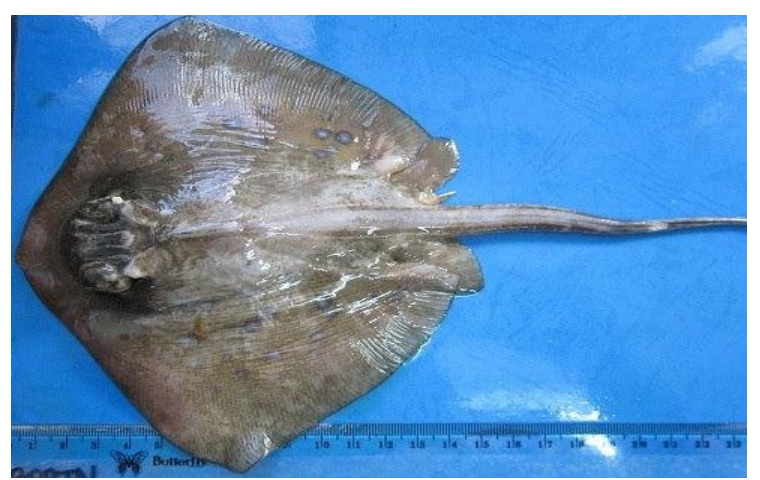

Gambar 1. Morfologi ikan pari blentik Neotrygon kuhlii. 
Klasper adalah alat seksual ikan pari jantan. Sedangkan untuk kematangan ikan pari blentik betina dilihat dengan pengamatan secara internal.

\section{Analisa data}

Hubungan panjang bobot

Model pertumbuhan ikan pari blentik diasumsikan mengikuti pola hukum kubik dari dua parameter yang dijadikan analisis yaitu parameter panjang dan bobot. Analisis hubungan panjang bobot masing-masing spesis ikan digunakan rumus sebagai berikut:

$$
\mathrm{W}=\mathrm{a} \mathrm{L}^{\mathrm{b}}
$$

Keterangan :

$$
\begin{aligned}
\mathrm{W} & =\text { bobot ikan } \\
\mathrm{L} & =\text { panjang ikan } \\
\mathrm{a}, \mathrm{b} & =\text { konstanta }
\end{aligned}
$$

\section{Faktor kondisi}

Faktor kondisi (K) digunakan dalam mempelajari perkembangan gonad ikan jantan maupun betina yang belum dan sudah matang gonad, dihitung dengan menggunakan hubungan sebagai berikut:

$$
\mathrm{K}=\mathrm{W} /\left(\mathrm{aL}^{3}\right)
$$

$\mathrm{K}$ adalah faktor kondisi, W adalah bobot tubuh ikan contoh $(\mathrm{g}), \mathrm{L}$ adalah panjang total ikan contoh $(\mathrm{mm})$ dan a adalah konstanta.

\section{Ukuran pertama kali matang gonad}

Metode yang digunakan untuk menduga ukuran rata-rata ikan pari mencapai matang gonad (M) untuk ikan yang memiliki TKG III, TKG IV dan TKG V adalah Metode SpearmanKarber yang menyatakan bahwa logaritma ukuran rata-rata mencapai matang gonad adalah (Udupa, 1986):

$$
\mathrm{m}=\mathrm{x}_{\mathrm{k}}+(\mathrm{d} / 2)-\left(\mathrm{d} \times \sum \mathrm{P}_{\mathrm{i}}\right)
$$

$\mathrm{m}$ adalah logaritma dari kelas panjang pada kematangan pertama, $\mathrm{d}$ adalah selisih logaritma dari pertambahan nilai tengah panjang, $\mathrm{k}$ adalah jumlah kelas panjang $x_{k}$ adalah logaritma nilai tengah panjang ikan matang gonad (atau dimana $\mathrm{P}_{\mathrm{i}}=1$ ). Mengantilogkan persamaan di atas, maka Lm dapat diduga $\alpha=0,05$ maka:

Batas-batas kepercayaa 95\% dari $(\mathrm{m})=$ $\operatorname{antilog}\left(\mathrm{m} \pm 1,96 \sqrt{ }\left[\mathrm{x}^{2}\left(\mathrm{P}_{\mathrm{i}}-\mathrm{Q}_{\mathrm{i}}\right) /\left(\mathrm{N}_{\mathrm{i}}-1\right)\right]\right.$

\section{Tingkat kematangan gonad}

Jenis kelamin diduga berdasarkan pengamatan gonad ikan selama penelitian. Tingkat kematangan gonad adalah tahap perkembangan gonad sebelum dan sesudah ikan memijah (Smith et al., 2007). Tingkat kematangan gonad yang ditentukan secara morfologi didasarkan pada bentuk, warna, ukuran bobot gonad, dan perkembangan isi gonad. Tingkat kematangan gonad (TKG) ikan jantan dan ikan betina ditentukan berdasarkan metode klasifikasi yang di buat Eber dan Cowley (2009) yang ditampilkan pada Tabel 1.

\section{Indeks kematangan gonad}

Indeks kematangan gonad yaitu suatu nilai dalam persen sebagai hasil dari perbandingan berat gonad dengan berat tubuh ikan termasuk gonad dikalikan dengan 100. Sejalan dengan perkembangan gonad, maka bobot semakin bertambah dan semakin besar sampai mencapai maksimum ketika ketika ikan memijah. Perhitungan dilakukan menggunakan rumus:

$$
\mathrm{IKG}=\mathrm{BG} / \mathrm{BT} \times 100
$$

$$
\begin{aligned}
& \text { Keterangan : } \\
& \begin{aligned}
\mathrm{IKG} & =\text { indeks kematangan gonad } \\
\mathrm{BG} & =\text { berat gonad ikan }(\mathrm{g}) \\
\mathrm{BT} & =\text { berat tubuh ikan }(\mathrm{g})
\end{aligned}
\end{aligned}
$$

\section{HASIL DAN PEMBAHASAN}

\section{Hasil}

Hubungan panjang dan bobot

Analisis hubungan panjang dan bobot dilakukan dengan menggunakan data panjang dan bobot ikan pari blentik sebanyak 150 ekor yang terdiri dari 78 ekor ikan betina dan 72 ekor ikan jantan. Hubungan panjang dan bobot dapat diamati pada Gambar 2 dan Gambar 3.

\section{Faktor kondisi}

Faktor kondisi menunjukkan keadaan baik pada ikan dilihat dari kapasitas fisik untuk survival dan untuk reproduksi. Faktor kondisi (Tabel 2 dan Tabel 3) dapat naik dan turun karena merupakan indikasi dari musim saat ikan tersebut melakukan pemijahan, khususnya ikan-ikan betina.

\section{Ukuran pertama kali matang gonad}

Ukuran pertama kali matang gonad merupakan salah satu parameter yang penting dalam penentuan ukuran terkecil ikan yang dapat ditangkap. Awal kematangan gonad umumnya 
ditentukan berdasarkan umur atau ukuran ketika $50 \%$ individu di dalam suatu populasi sudah matang gonad (Hale et al., 2008). Kisaran ukuran pertama kali matang gonad ikan pari blentik betina dengan kisaran panajng total tubuh 550-799, sedangkan untuk ikan pari jantan dengan kisaran panjang total tubuh 550-760 $\mathrm{mm}$ (Tabel 4).
Proses pembiakan pada ikan dimulai pada saat mencapai tingkat kematangn gonad atau kedewasaan pada saat ukuran tertentu. Tercapainya ukuran tersebut tergantung dari faktor lingkungan, ekologi dan ciri-ciri biologi ikan itu sendiri (Griffiths et al., 2006). Dugaan rata-rata ukuran pertama kali matang gonad untuk

Tabel 1. Tingkat kematangan gonad (TKG) ikan pari Dasyatis kuhlii menurut Eber dan Cowley (2009)

\begin{tabular}{|c|c|c|}
\hline TKG & Betina & Jantan \\
\hline I & $\begin{array}{l}\text { Ovarium tidak terlihat jelas serta saluran } \\
\text { oviduk tidak terlihat dalam rahim }\end{array}$ & $\begin{array}{l}\text { Memiliki klasper yang pendek yaitu tidak } \\
\text { melampaui tepi posterior sirip dubur }\end{array}$ \\
\hline II & $\begin{array}{c}\text { Ovarium terlihat jelas tetapi tidak memiliki } \\
\text { oosit matang, saluran oviduk belum } \\
\text { berkembang }\end{array}$ & $\begin{array}{l}\text { Klasper melampaui tepi posterior sirip dubur } \\
(3-6 \mathrm{~cm}) \text {, tetapi tidak memiliki klasifikasi } \\
\text { dari unsur-unsur tulang rawan terminal }\end{array}$ \\
\hline III & $\begin{array}{c}\text { Terdapat oosit yang berwarna kuning } \\
\text { berdiameter } 1,5-2,0 \mathrm{~cm} \text {., saluran oviduk yang } \\
\text { terlihat jelas, atau sudah terdapat embrio yang } \\
\text { berkembang di dalam rahim }\end{array}$ & $\begin{array}{c}\text { Panjang klasper mencapai } 6-9 \mathrm{~cm} \text { melampau } \\
\text { tepi posterior sirip dubur dan memiliki } \\
\text { klasifikasi dari unsur-unsur tulang rawan } \\
\text { terminal }\end{array}$ \\
\hline
\end{tabular}

Tabel 2. Faktor kondisi ikan pari blentik betina selama penelitian

\begin{tabular}{ccc}
\hline Jumlah & Rata-rata faktor kondisi & Simpangan baku \\
\hline- & - & - \\
8 & 1,0852 & 0,6716 \\
18 & 1,0454 & 0,3072 \\
32 & 1,0426 & 0,2620 \\
7 & 1,0375 & 0,2514 \\
12 & 1,2113 & 0,2235 \\
- & - & - \\
- & - & - \\
1 & 0,4779 & - \\
\hline
\end{tabular}

Tabel 3. Faktor kondisi ikan pari blentik jantan selama penelitian

\begin{tabular}{ccc}
\hline Jumlah & Rata-rata faktor kondisi & Simpangan baku \\
\hline 1 & 2,8074 & - \\
1 & 1,7055 & - \\
11 & 0,6970 & 0,1195 \\
29 & 0,9955 & 0,2859 \\
16 & 1,2295 & 0,3774 \\
8 & 1,4825 & 0,4433 \\
2 & 0,8912 & 0,0207 \\
3 & 0,8251 & $0 \mathrm{E}-10$ \\
1 & 0,7618 & - \\
\hline
\end{tabular}


ikan pari N. kuhlii betina dengan melihat adanya telur atau emrio yang berada di dalam perut ikan pari. Adanya perbedaan dalam kecepatan tumbuah pada setiap sampling serta adanya perbedaan kondisi perairan menyebabkan. Ikan pari blentik $N$. kuhlii di beberapa perairan Indonesia memiliki ukuran pertama kali matang gonad yang berbedabeda (White et al., 2006)

\section{Tingkat kematangan gonad}

Menurut Dharmadi dan Fahmi (2006), pengamatan terhadap gonad ikan dilakukan secara morfologi yang didasarkan pada bentuk, warna, ukuran, bobot gonad, serta perkembangan isi gonad. Ikan pari blentik yang diperoleh selama pengamatan didominasi oleh ikan yang belum matang gonad.

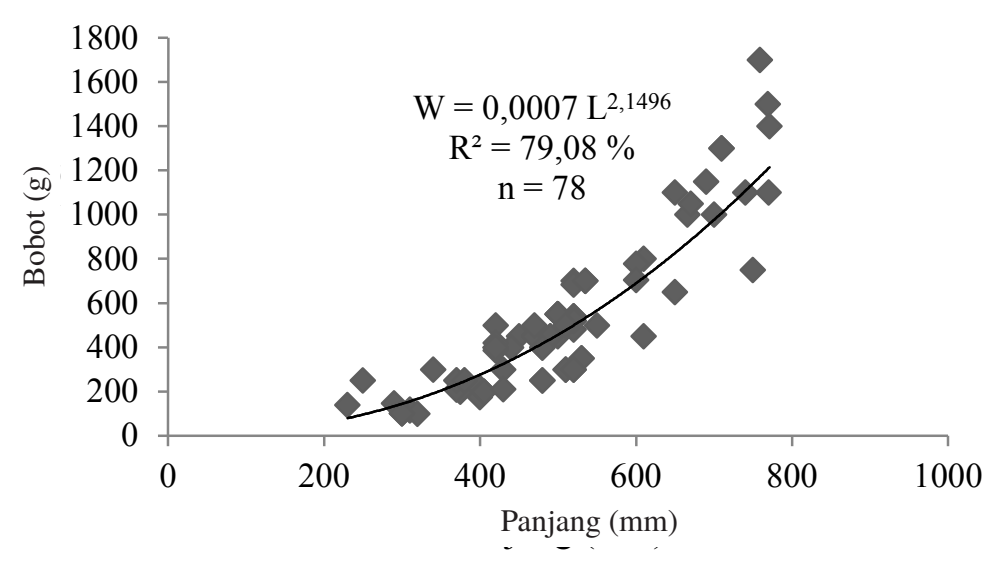

Gambar 2. Hubungan panjang dan bobot ikan pari blentik betina

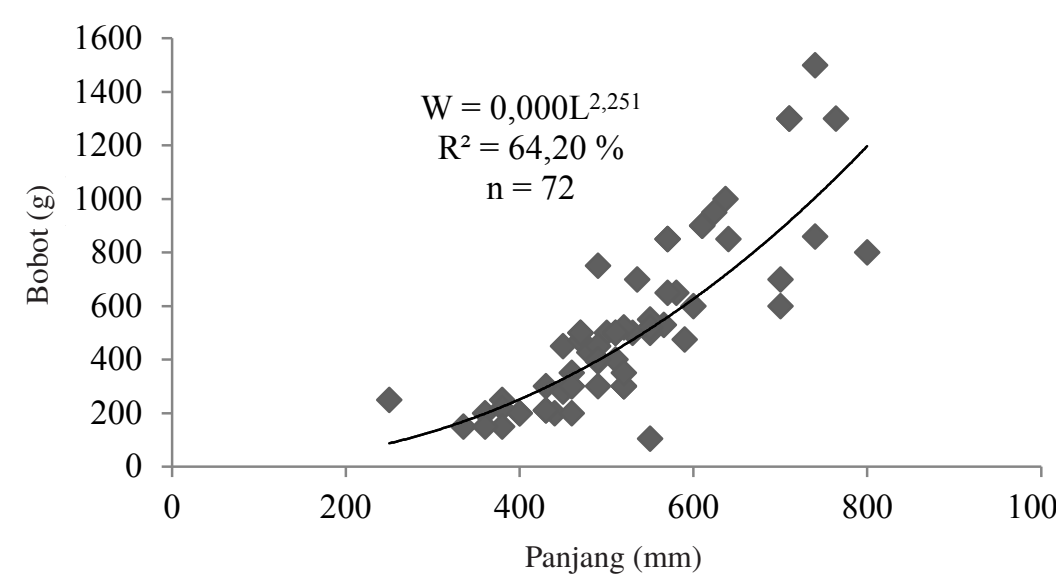

Gambar 3. Hubungan panjang dan bobot ikan pari blentik jantan

Tabel 4. Distribusi (ekor) tingkat kematangan gonad ikan pari Neothrygon kuhlii jantan dan betina berdasarkan kisaran panjang tubuh $(\mathrm{mm})$ yang didapatkan selama penelitian

\begin{tabular}{cccc}
\hline Panjang total $(\mathrm{mm})$ & Jantan & Betina & Jumlah matang gonad \\
\hline $335-771$ & 3 & 1 & 4 \\
$250-1055$ & 1 & 3 & 4 \\
$230-770$ & 5 & 4 & 9 \\
$290-310$ & 0 & 0 & 0 \\
$300-710$ & 3 & 4 & 7 \\
$320-690$ & 5 & 0 & 5 \\
$300-710$ & 14 & 5 & 19 \\
\hline
\end{tabular}




\section{Indeks kematangan gonad}

Indeks kematangan gonad (IKG) adalah suatu nilai dalam persen yang merupakan nilai dari perbandingan antara bobot gonad dan bobot ikan dikalikan $100 \%$. Indeks kematangan gonad diperlukan sebagai salah satu pengukuran aktivitas yang terjadi di dalam gonad. Selanjutnya dikatakan bahwa bobot gonad akan mencapai maksimum sesaat sebelum ikan memijah kemudian bobot gonad akan menurun dengan cepat selama pemijahan sedang berlangsung sampai selesai (Fahmi et al, 2009).

Indeks kematangan gonad ikan betina lebih tinggi dari ikan jantan pada TKG yang sama, disebabkan karena IKG sangat dipengaruhi oleh bobot gonad dan bobot tubuh (Saputra et al., 2009. Gonad yang berisi telur (betina) lebih berat dibandingkan gonad yang berisi sperma (jantan), sehingga IKG ikan betina lebih tinggi dibanding ikan jantan (Jacobsen et al., 2012). Grafik indeks kematangan gonad ikan pari blentik betina dan jantan dapat diamati pada Gambar 6 .

Berdasarkan analisis tersebut menunjukkan bahwa nilai kisaran IKG ikan jantan lebih besar dibandingkan ikan betina pada TKG yang sama (Gambar 7). Hal ini sesuai dengan hasil penelitian Chavert-Almeida et al. (2005) yang cmenyatakan bahwa, ikan freshwater stingrays (Patomatrygonidae) dan nervous shark Carcharhinus cautus pada kelas Chondrichthyes, IKG ikan jantan lebih besar dibandingkan ikan betina. Diduga karena oosit yang berada didalam ovari memiliki endapan kuning telur yang sudah sangat tereduksi, disebabkan ketika telur telah dibuahi oleh sperma kemudian menjadi embrio, tidak memiliki cadangan makanan dari kuning telur melainkan mendapatkan makanan langsung dari induknya.

\section{Pembahasan}

Jumlah contoh yang diperoleh sebanyak 150 ekor terdiri atas 78 ekor ikan betina dan 72 ekor ikan jantan. Hasil analisis hubungan panjang bobot ikan pari $N$. kuhlii diketahui bahwa persamaan pola pertumbuhan ikan pari betina $\mathrm{W}=0,0007 \mathrm{~L} 2,1496$ dengan koefisien determinasi (R) 79\%, sedangkan untuk ikan pari jantan adalah $\mathrm{W}=0,000 \mathrm{~L} 2,251$ dengan koefisien determinasi (R) 64\%. Hasil setelah dilakukan uji $\mathrm{t}$ menunjukkan bahwa koefisien regresi kurang dari 3 (b<3). Hal ini menunjukan bahwa ikan pari blentik memiliki pola pertumbuhan allometrik negatif artinya, pertambahan panjang lebih dominan daripada pertambahan bobot.
Tingkat kematangan gonad ikan jantan maupun betina pada setiap waktu pengambilan sampel tidak sama atau beragam sehingga memungkinkan ikan pari memijah lebih dari satu kali setahun. Akan tetapi masa kehamilan ikan pari menurut Eber dan Cowley (2009) adalah masa kehamilan sembilan bulan karena ikan pari memerlukan waktu yang cukup lama dalam merawat embrio sehingga embrio berkembang dan dapat dilahirkan. Hal ini berarti ikan pari mempunyai siklus pemijahan tahunan dengan masa mengandung sembilan bulan.

Hasil penelitian yang menunjukkan ukuran rata-rata pertama kali matang gonad untuk ikan jantan dan betina berbeda. Hal ini berkaitan dengan perbedaan jenis kelamin dan pertumbuhan ikan itu sendiri. Portnoy et al. (2012) menyatakan beberapa faktor yang mempengaruhi saat ikan pertama kali matang gonad antara lain adalah perbedaan spesies, umur dan ukuran, serta sifatsifat fisiologi individu yang berbeda jenis kelamin dan juga berpijah yang sesuai.

Hasil penelitian menunjukkan pola pertumbuhan ikan pari blentik baik jantan maupun betina N. kuhlii di perairan Selat Sunda bersifat allometrik negatif artinya pertambahan panjang lebih dominan daripada pertambahan bobot. Pola pertumbuhan yang diperoleh berdasarkan hasil penelitian ini berbeda dengan hasil penelitian lainya dengan beberapa spesies pari yang berbeda pada Tabel 4. Perbedaan nilai $b$ pada Tabel 4 dipengaruhi oleh adaanya perbedaan laju pertumbuhan, perbedaan umur, tahap perkembangan gonad, serta makanan dan kondisi perairan (Ward et al., 2008)

Perbandingan yang diperoleh antara ikan pari blentik betina dan jantan adalah 1,2:1. Proporsi ikan pari blentik betina dan jantan dalam populasi dalam keadaan tidak seimbang (1:1 seimbang). Setelah diketahui jenis kelamin ikan, dilakukan pengamatan pada gonad individu ikan untuk penentuan TKG. (Lipej et al., 2012) Tingkat kematangan gonad diperlukan untuk mengetahui informasi tentang kapan ikan memijah atau sudah selesai memijah.

Ikan pari N. kuhlii dengan TKG III banyak terdapat pada Juni dan Juli (Gambar 3 dan 4). Ikan pari blentik yang matang gonad mulai mengalami peningkatan jumlah pada bulan Juni dan Juli, sehingga diduga musim puncak pemijahan ikan pari blentik berada pada bulan tersebut. Oleh karena itu, dari segi aspek pengaturan pengelolaannya penangkapan ikan pari sebaiknya dikurangi pada bulan Juni-Juli 
karena telah memasuki musim puncak pemijahan yaitu saat terdapat banyak ikan yang telah matang gonad.

Faktor kondisi ikan pari betina pada setiap waktu pengamatan cenderung tinggi dibandingkan dengan jantan. (Pralampita \& Mardlija, 2006) Penurunan faktor kondisi ikan pari betina dapat disebabkan oleh baru selesai memijah atau sedang beradaptasi dengan lingkungan. (Raharjo
\& Simanjutak, 2008) menjelaskan faktor kondisi ikan bergantung pada berbagai faktor yakni faktor eksternal lingkungan dan faktor internal diantaranya kematangan gonad.

Analisis ukuran rata-rata matang gonad (Lm50) pada penelitian ini dianalisis dengan menggunakan metode Spearman-Karber (Udupa, 1986). Kisaran ukuran pertama kali matang gonad ikan pari blentik betina dengan kisaran

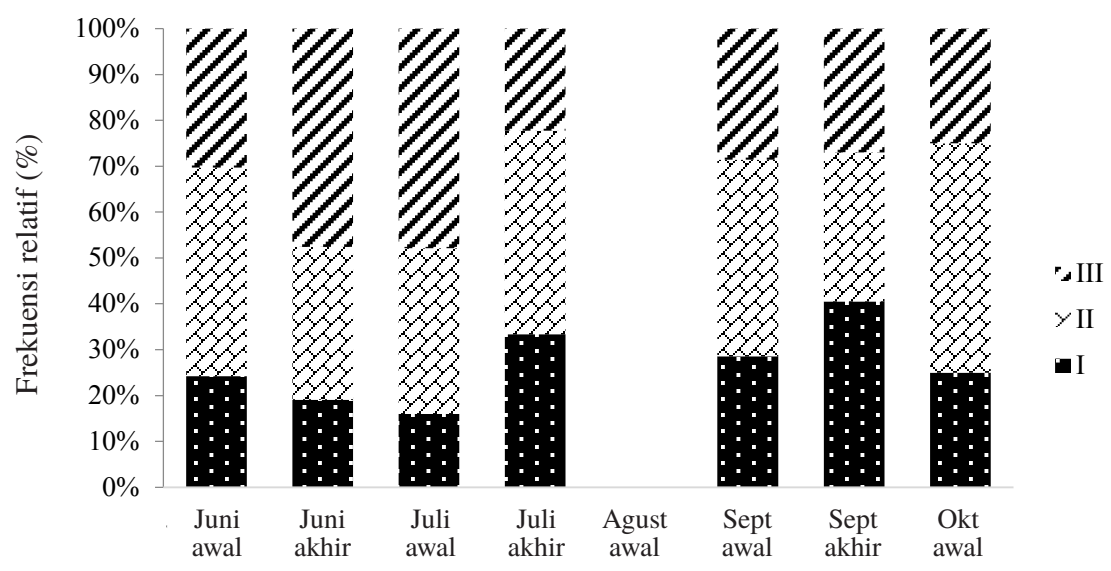

Waktu pengambilan contoh

Gambar 4. Tingkat kematangan gonad ikan pari blentik Neotrygon kuhlii betina di Selat Sunda

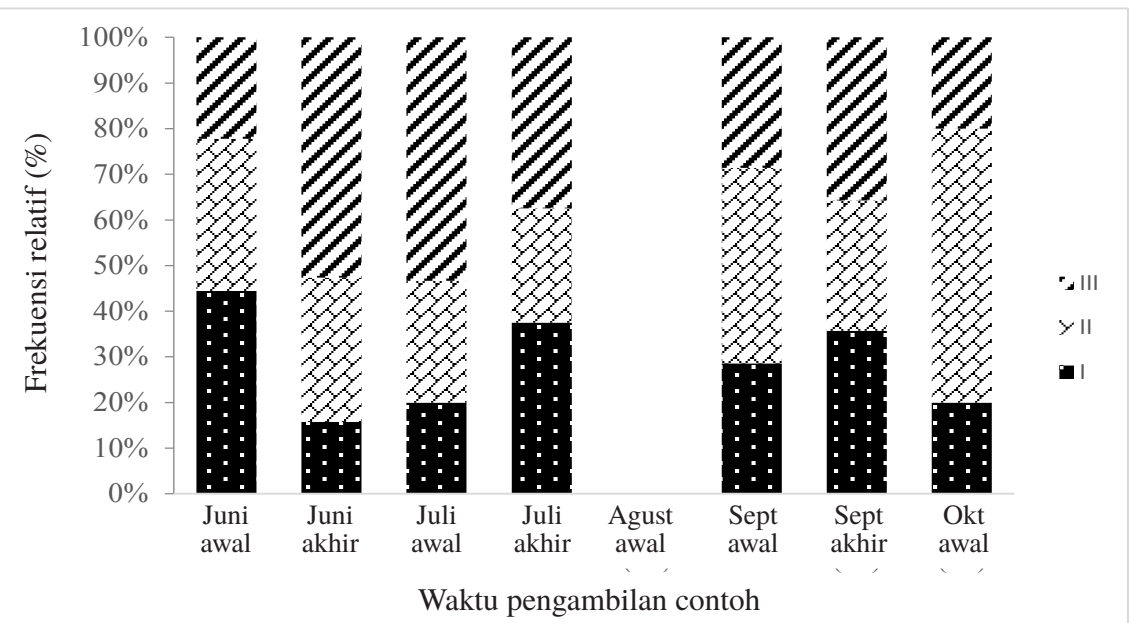

Gambar 5. Tingkat kematangan gonad ikan pari blentik Neotrygon kuhlii jantan di Selat Sunda

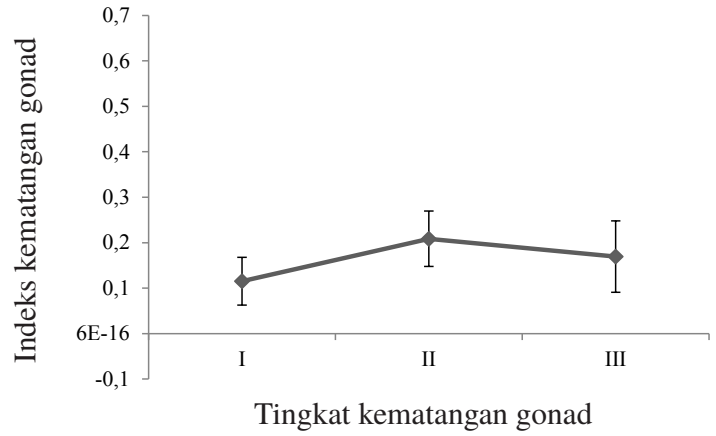

Gambar 6. Indeks kematangan gonad ikan pari blentik Neotrygon kuhlii jantan di Selat Sunda.

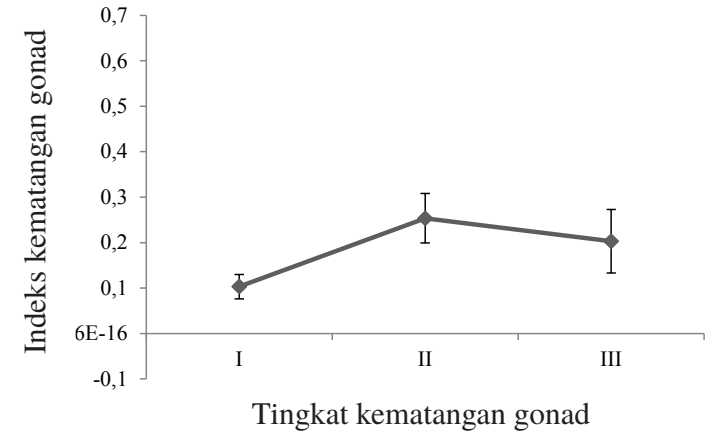

Gambar 7. Indeks kematangan gonad ikan pari blentik Neotrygon kuhlii jantan di Selat Sunda. 
panjang total tubuh 550-799, sedangkan untuk ikan pari jantan adalah dengan kisaran panjang total tubuh 550-760 mm. Ketersediaan makanan merupakan salah satu hal yang berpengaruh terhadap keseimbangan habitat. Ketersediaan bahan makanan yang cukup akan mempercepat laju pertumbuhan ikan pari blentik. Faktor ketersediaan makanan juga menjadi faktor yang menentukan jumlah populasi, pertumbuhan, reproduksi, dan dinamika populasi serta kondisi ikan yang ada di perairan. Ikan pari blentik $(\mathrm{N}$ kuhlii) memanfaatkan anakan ikan, udang dan krustacea sebagai makanannya (Lipej et al., 2012)

Pengamatan menunjukkan potensi sumberdaya ikan pari blentik di perairan Selat Sunda mulai menurun. Hal ini ditunjukkan dengan tertangkapnya ikan-ikan kecil selama penelitian berlangsung, ukuran ikan terkecil yang tertangkap adalah $100 \mathrm{~mm}$. Penggunaan alat tangkap dengan ukuran mata jaring yang kecil mengakibatkan ikan-ikan kecil ikut tertangkap. Jika ikan-ikan yang belum sempat memijah tertangkap maka proses rekrutmen pada populasi ikan tersebut akan terganggu dan pada akhirnya mengancam kelestarian sumberdaya ikan tersebut.

\section{KESIMPULAN}

Pola pertumbuhan ikan pari blentik allometrik negatif. Ikan pari blentik memasuki musim puncak pemijahanya pada bulan Juni dan Juli. Ikan pari jantan lebih cepat matang gonadnya dibandingkan dengan ikan pari betina. Kisaran ukuran pertama kali matang gonad ikan pari blentik betina dengan kisaran panajng total tubuh 550-799, sedangkan untuk ikan pari jantan dengan kisaran panjang total tubuh 550-760. Indeks kematangan gonad (IKG) ikan pari semakin meningkat seiring dengan meningkatnya TKG. Ikan pari memijah secara keseluruhan atau satu kali dalam satu musim pemijahan (total spawner).

\section{DAFTAR PUSTAKA}

Candramila W, Junardi. 2006. Komposisi keanekaragaman dan rasio kelamin ikan elesmobranchii asal sungai kakap Kalimantan Barat. Biospecies 1: 41-46.

Chavert-Almeida PM, LG DE Araujo, and MP De Almeida. 2005. Reproducitive aspects of freshwater stingrays (Chondrichthyes: Patamotrygonidae) in the Brazilian Amazon Basin. Journal of Northwest Atlantic Fishery Science 35: 165-171.
Dharmadi, Fahmi. 2006. Tingkat kematangan kelamin dan frekuensi panjang pari gitar Rhinobatus sp. dan Rhinobatus sp. Jurnal Bawal 1: 31-35.

Eber DA, Cowley PD. 2009. Reproduction and embryonic development of the blue stingray Dasyatis chrysonotanin Southern African Waters. Journal of Marine Biological Association of the United Kingdom 89: 80-81.

Fahmi, Mohammad A, Dharmadi. 2009. Size at first maturity of the blue spotted maskray, Neotrygon kuhlii in Indonesian Waters. Indonesia Fisheries Research Journal 15: 29-35.

Griffiths SP, Brewer DT, Heales DS., Milton DA, Stobutzki IC. 2006. Validatingecological risk assessments for fisheries: assessing the impacts of turtle excluder devices on elasmobranch bycatch populations in an Australian trawl fishery. Marine Freshwater Research 57: 395-401.

Hale LF, Lowe CG. 2008 . Age and growth of the round stingray Urobatis halleri at Seal Beach, California. Journal of Fish Biology 73: 510-523.

Jacobsen I, Bennett M. 2012. Feeding ecology and dietary comparisons among three sympatric Neotrygon (Myliobatoidei: Dasyatidae) species. Journal of Fish Biology 80: $1.580-1.594$.

Last PR, Steves JD. 2009. Shark and Rays of Australia, $2^{\text {nd }}$ ed. Australia: Commonwealth Scientific and Industrial Research Organisation.

Lipej L, Mavric B, Paliska D, Capap. 2012. Feeding habits of the pelagic stingray Pteroplatytrygon violacea (Chondrichthyes: Dasyatidae) in the Adriatic Sea. Journal of the Marine Biological Association of the United Kingdom 1: 1- 6 .

Pierce SJ, Pardo SA, Bennett MB. 2009. Reproduction of the blue-spotted maskray Neotrygon kuhlii (Myliobatoidei: Dasyatidae) in south-east Queensland, Australia. Journal Fish Biology 74: 1.291-1.308.

Portnoy DS, Heist EJ. 2012. Molecular markers: progress and prospects for understanding reproductive ecology in elasmobranchs. Fish Biology. 86: 1095-2011.

Pralampita WA, Mardlija S. 2006. Aspek biologi pari mondol Himatura gerardi, Famili Dasyatidae dari perairan Laut Jawa. Jurnal Penelitian Perikanan Indonesia 12: 69-75.

Puckridge M, Last PR, White WT, Andreakis 
N. 2013. Phylogeography of the Indo-West Pacific maskrays (Dasyatidae, Neotrygon): A complex example of chondrichthyan radiation in the Cenozoic. Jurnal Ecology 3: 21-32.

Raharjo MF, Simanjutak CPH. 2008. Hubungan panjang bobot dan faktor kondisi ikan tetet Johnius belangeri di Perairan Pantai Mayangan, Jawa barat. Jurnal Ilmu-ilmu Perairan dan Perikanan indonesia 15: 135-140.

Saputra SW, Prijadi S, Gabriela AS. 2009. Beberapa aspek biologi ikan kuniran Upeneus spp. di Perairan Demak. Jurnal Saintek Perikanan 5: 1-6.

Smith WD, Cailliet GM, Melendez EM. 2007. Maturity and growth characteristics of a commercially exploited stingrays Dasyatis dipterura. Marine and Freshwater Research 58: 54-66.

Udupa KS. 1986. Statistical metod of estimating the size of first maturity of fishes. Fishbyte 4:
8-10.

Ward RD, Holmes BH, White WT, Last PR. 2008. DNA barcoding Australasian chondrichthyans: results and potential uses in conservation. Marine and Freshwater Research 59: 57-71.

White WT. 2003. Aspect of the Biology of Elasmobranchs in a Subtropical Embayment in Western Australia and of Chondrichthyan Fisheries in Indonesia. Western Australia: Mordoch University.

White WT, Giles J, Dharmadi, Potter IC. 2006. Data on the bycatch fishery and reproductive biology of mobulid rays (Myliobatiformes) in Indonesia. FisheriesResearch 82: 65-73.

White WT, Dharmadi. 2007. Species and size compositions and reproductive biology of rays (Chondrichthyes, Batoidea) caught in target and non-target fisheries in eastern Indonesia. Journal of Fish Biology 70: 1.809-1.837. 